Presidential Address

\title{
The Current Economic Crisis and Lessons for Economic Theory
}

Joseph E. Stiglitz

Uris Hall, Room 814, Columbia University 3022 Broadway, New York, NY 10027, USA.

Eastern Economic Journal (2009) 35, 281-296. doi:10.1057/eej.2009.24

These are exciting times: the worst economic crisis since the Great Depression, the first global recession in the new era of globalization, and a new President committed to restructuring national priorities, reforming our education, health, and energy sectors, eliminating some long standing distortions arising from corporate welfare, and restructuring our tax code. For economists who have fought long for many of these ideas, the President's budget was a moment of celebration. The final recognition that the atmosphere is a global public good, that we have failed to price one of the most scarce economic resources, and that going forward we would do so, was music to an economist's ear.

There will be political battles ahead. Special interests will try to block many of the reforms. The future of our nation will depend in no small measure on the outcome of those battles.

Today, however, I do not want to dwell on these great initiatives. I want to address two issues. The first is a matter of immediacy: what should we do about our failed banks? The second is a matter of reflection: what role did we, the economics profession, or more precisely, what role did some of the ideas that had become fashionable, even dominant, play in causing this crisis? What lessons will or should we take away? How should it affect what we teach, what we advise governments to do, and what our research agenda is?

\section{THE CRISIS}

Turning first to the crisis. We have at long last emerged from the paralysis, from the period of denial, from the notion that recovery was around the corner. For years, it has been clear that America's growth was not sustainable. It was based on a real estate bubble, which sustained a consumption boom. America was living beyond its means.

Alan Greenspan may have been right that you could not be sure that there was a bubble until after it broke, but policy-makers are supposed to make decisions based on the analysis of risk. The likelihood that there was a bubble was increasingly clear; and the more housing prices grew, the greater the likelihood that the eventual crash would be disastrous. How could prices continue to grow, especially for housing for lower and middle-income individuals, as incomes stagnated? One doesn't have to have a Ph.D. to know that you can't spend more than 100 percent of your income on housing. Over inflated housing prices allowed Americans to take out hundreds of billions of dollars in mortgage equity withdrawals, in 1 year alone an estimated US\$900 billion.

It has also long been clear what was required: a stimulus package, a program to deal with the housing market, and a program to deal with the financial sector. 
For months, nothing was done on the first two, and what was done on the third was totally ineffective. It is such a relief that finally something is being done that I hesitate to raise a note of criticism. But regrettably, I do not believe we are doing enough, or the right thing, in any of these areas. Let me be clear: what we are doing is much, much better than doing nothing, or doing what we were doing. It will make a difference, but it is likely not enough. A year from now the economy will remain weak, the housing problems will still be with us, and our banks will still be ailing.

\section{THE GLOBAL CONTEXT}

Before turning to what we should be doing, I want to spend a moment discussing the global context. The current financial crisis, which began in the US, then spread to Europe, has now become global. Even emerging markets and less developed countries that managed their economy well, resisted the bad lending practices, held high levels of foreign exchange reserves, did not purchase toxic mortgages, and did not allow their banks to engage in excessive risk taking through derivatives are likely to become embroiled and to suffer as a result. Any global solution - short-term measures to stabilize the current situation and long-term measures to make another recurrence less likely - must pay due attention to impacts on these countries. Without doing so, global economic stability cannot be restored, and economic growth, as well as poverty reduction worldwide, will be threatened.

The countries in East Asia emerged from their crisis a decade ago relatively quickly, because they could turn to export markets. Last year, the one source of economic strength in the US was exports. But now, with most countries in a downturn, we cannot export our way out of this crisis.

A global crisis requires a global response, yet so far our responses are national. Each country will be focusing on its own trade-offs, the stimulus that it gets from spending versus the costs in increased national indebtedness, for example. The benefits to other countries from increased spending are externalities, which they won't take into account, unless there is coordinated action. Worse still, each country will be tempted to maximize its own multiplier by beggar thy neighbor policies, like the "buy America" provision included in the stimulus package. Although there was a sigh of relief when additional language was put in suspending that provision, to the extent that it violated international agreements, curiously this made the provision in some ways even more invidious, because we have plurilateral government procurement agreements with other advanced industrial countries but not with most developing countries. In short, we will discriminate against the poor developing countries that need our help even more.

If each country only focuses on its own interests, some countries will be tempted to be free riders. The size of the global stimulus will thus be smaller than needed, and the global impact will be smaller, as each strives to find those expenditures that have the largest domestic multipliers, regardless of the global multipliers. There is a huge difference between domestic and global multipliers, and an effective global response needs to focus on the global multipliers.

America has a special obligation to behave responsibly. This crisis has a clear "Made in the USA" label on it. We made the toxic mortgages and then exported them - about half of them, in fact. Once again, we have benefited from globalization: had we not exported so many, we would have even deeper crisis here. Our banks would be in even worse trouble. We exported the deregulatory 
philosophy, which meant that many elsewhere didn't put into place the safeguards that would have stopped them from buying these toxic products. Now we have exported our recession.

With President Obama's election, America has a unique opportunity to repair the enormous damage to our international relations of the previous 8 years. However, this opportunity will be lost if we are seen to be advancing our own parochial interests at the expense of others. It has been commonplace to recite the damage to the global economy from the Smoot-Hawley tariffs. We are unlikely to do anything so overt, but intentionally or unintentionally, what we do may have adverse effects on others. There is concern about what we have done and how we have done it.

Governments have intervened in markets in an almost unprecedented way - and even as some governments call for more transparency, we have to recognize that much of what has been done has been highly non-transparent. With expenditures of this scale and a lack of transparency of this scope, vast opportunities for corruption and untoward redistributions are opened up. We have been moving in unchartered territory.

The distortions created in the market economy will be long lasting. There can be no level playing field, with governments in some developed countries offering multibillion dollar subsidies to their enterprises that poor countries simply cannot match. Even symmetric policies can have asymmetric effects: a government guarantee to a bank deposit from the US has more credibility than one from a poor developing country.

Matters are even worse in financial markets, as firms in some developed countries receive hundreds of billions of dollars of assistance, well beyond the GDP of poorer countries. Even the knowledge that failure can be met with a bailout changes the willingness and ability to undertake risk.

The global economic landscape has changed unalterably. We cannot go back to the world before September 15. The question is, what kind of world will it be?

In the past, the global financial system often worked to the disadvantage of developing countries. Banks in developed countries, for instance, were encouraged to lend short term to developing countries; while this provided greater liquidity to the former, it led to greater instability in the latter. In good years, financial and capital market liberalization may have provided additional funding to some developing countries. However, in bad years, the funds that flowed so freely are withdrawn. Pro-cyclical monetary and fiscal policies were often foisted on developing countries, while developed countries followed countercyclical policies.

These asymmetries mean that there is greater risk in developing countries, forcing them to pay a higher cost of capital. Combined with the guarantees and bailouts, these asymmetries also partially account for the anomalous situation where money is flowing from developing countries back to the US, from whence the global problems originated.

It is understandable that each country focus first and foremost on its own citizens and its own economy, but it would be a mistake not to recognize the consequences of our actions. At the very least, we may need to provide compensatory payments to offset the damage that we have done to others. This is not the time to be cutting back on foreign assistance; this is the time to increase it.

The rest of the world will be watching carefully what the US does. Are we assuming our responsibilities? How we respond will have much to do not only with how quickly and robustly the world emerges from this crisis, but also with the nature 
of the global economy in the post crisis world. Will there be closer economic integration? Or will there be a retreat from globalization?

\section{AMERICA'S RESPONSE TO THE CRISIS}

Let me now turn to the three elements of America's response to the crisis.

\section{The stimulus}

Within the economics profession, there is, I think, a clear understanding of what makes for a good stimulus: it has to work quickly (we say, be timely), it should have a big bang for the buck, and it should help - and certainly not worsen - our long run problems. Having a big bang for the buck is especially important because of the growth in the size of the national debt, from $\$ 5.7$ trillion in the beginning of the Bush Administration to over $\$ 10$ trillion today, with an expected deficit this year of $\$ 1.5$ to $\$ 2$ trillion, depending on how one does the calculations. (If we use standard accounting procedures, of the kind that the IMF employs, which consolidate government owned enterprises into the government's debt, we would have to add another $\$ 5$ trillion or so as a result of the government take-over of Fannie Mae and Freddie Mac.)

But most economists were never enamored of standard government accounting, which focuses on liabilities and pays no attention to assets. If we spend money to create assets (new technology, infrastructure, human capital), then these assets offset the new liabilities, and the national balance sheet can even be strengthened.

These criteria imply that the tax cuts, which comprise about a third of the stimulus package, don't make the mark. Americans are likely to save significant fractions of the tax cut because they are saddled with heavy debt, have uncertainties about access to credit and job insecurity, and had large fractions of their wealth destroyed because of falling asset prices. This means that the tax cuts are not likely to provide much stimulus.

In assessing the appropriate size of the stimulus, we need to take into account the negative stimulus coming from the automatic destablizers built into state expenditures. Most states have balanced budget frameworks. This means that when tax revenues fall - as they do when the economy goes into a recession and when real estate prices plummet - they either have to cut back on expenditures or raise taxes. California alone has faced a shortfall of $\$ 40$ billion. A little while ago, the shortfall of the States was estimated to be around $\$ 150$ billion per year; but as the crisis has deepened, that number has increased. Thus, almost half of the stimulus simply offsets the negative stimulus coming from the states. We should have enacted a simple revenue sharing arrangement, making up for states' revenue shortfalls. The stimulus package will be helping the states significantly but not enough. Once we take into account the negative stimulus from the states, we see how inadequate is our stimulus - a net of 1-2 percent of GDP. (Of course, further stimulus will be provided by the "automatic stabilizers" built into government programs.)

The question is, what is the magnitude of the potential insufficiency in aggregate demand? By some reckoning, in the US there has been wealth destruction (not in the real sense, but in the sense of individuals' balance sheets) of $\$ 15$ trillion, an amount equal to GDP. A reduction of this magnitude could be expected to generate a reduction in consumption of between 5 and 6 percent of GDP. The drop in 
consumption, perhaps over a period of a couple years, may be even larger. Americans were living beyond their income. They were borrowing to sustain their living standards, even as median real incomes declined, and now they are declining even more. It is not just that they won't be able to borrow because our financial system is not working the way it should; it is that they won't want to borrow, to continue what were clearly unsustainable levels of consumption. Already, the data show dramatic increases in America's household savings rates.

Compound this with decreases in investment and exports, and one begins to form a picture of the severity of the situation.

Focusing on global aggregate demand also helps us think about the recovery. What will replace the "housing bubble?" Another tech bubble? As I tried to explain in my book The Three Trillion Dollar War with Linda Bilmes, one of the reasons for the loose monetary policy that contributed to the bubble was that there would have been, in the absence of loose monetary policy, an insufficiency of aggregate demand.

As long as the dollar remains the reserve currency of choice, there will be a demand to increase dollar holdings - which means the exchange rate will be such as to ensure that imports exceed exports. Reserves increased enormously after the East Asia crisis, as countries learned the risks of the loss of economic sovereignty in a crisis. It was individually rational for each country to increase reserves, but it was systemically costly. Because there is a real risk that this crisis will not be handled well either, the demand for reserves may increase even further.

Growing inequality too has contributed to the lack of aggregate demand. We have redistributed income from those who would spend it to those that don't. For a while, we thought we could circumvent the problem by allowing Americans at the bottom and middle to continue spending anyway, by borrowing. But that was not sustainable.

So far, little, if anything, is being done to address either of these fundamental problems. And that means that even after we fix our financial system, there is little basis for optimism about a return to robust growth.

\section{Our foreclosure problem}

It seemed remarkable to me that we waited so long to do anything about the foreclosure problem, which in a sense was at the root of the financial sector's problem. We were pouring money into the banking system. It was like a mass blood transfusion to a patient who was suffering from internal hemorrhaging, without doing anything about the underlying problem.

Now, at last, we have begun to do something. We need to make housing more affordable to lower and middle-income Americans, and we have to quickly restructure many of the mortgages that are underwater. If we don't, every month more homes will go into foreclosure. Millions will lose their homes, and with that, their life savings. Meanwhile, as families are being forced out of their homes, the homes get trashed and gutted; in some communities, the government has finally stepped in - to remove the remains. In others, the blight spreads, and so even those who have been model citizens, borrowing prudently and maintaining their homes, find markets values depreciating beyond their worst nightmares.

We have on our hands a social and human tragedy.

One way we can make housing more affordable is to convert the mortgage tax deduction into a cashable tax credit. Right now, we pay 50 percent of the costs 
(interest and real estate) of upper middle-income Americans, but nothing for poor Americans. This is neither equitable nor efficient.

Another way is to make some of the low cost capital that we have been giving so generously to our big banks available to lower and middle-income homeowners. We are beginning to expand these programs, but not widely enough.

There are a number of easy ways of dealing with the foreclosure problem - such as bailing out the lenders at the same time as writing down the loans - which, in the absence of budget constraints and worries about future moral hazard, would make everyone (other than the ordinary taxpayer) happy. Individuals could stay in their homes, and lenders would avoid taking a hit to their balance sheets. Knowing that the government is taking this risk off of balance sheets would contribute to alleviating the credit crunch.

The challenge is how to save the homes of the hundreds of thousands of those who otherwise would lose their homes, and not bail out the lenders, who should be made to bear the consequences of their failures to assess risk. (Clearly, borrowers also share in the blame, but, for the most part, the lenders were, or should have been, far more financially sophisticated than the borrowers, especially most of those taking out sub-prime mortgages.)

One critical part of the answer is a "homeowners' Chapter 11" — a speedy restructuring of liabilities of poorer homeowners, modeled on the kind of relief that we provide for corporations who cannot meet their debt obligations. Chapter 11 is premised on the idea that keeping a firm going is critical for the firms' workers and other stakeholders. The firm's management can propose a corporate reorganization that the Courts review. If found acceptable, there is a quick discharge of debt - the corporation is given a fresh start. The homeowners' Chapter 11 is premised on the idea that no one gains from forcing a homeowner out of his home. There are large transactions costs associated with foreclosure, and typically, following foreclosure, there is a deterioration in house maintenance and adverse effects on the community.

Right now, we make it more difficult for a family to restructure their mortgage than to restructure what they owe on a yacht. Individuals should not be forced to go through an entire bankruptcy proceeding to restructure their housing debt, and that is the intent of the homeowners' Chapter 11.

One of the objections to these restructuring proposals is that speculators as well as true homeowners may reap the benefits. It is the latter, of course, whose welfare is of particular concern. One way of addressing the problem is to restrict eligibility to those who are and have been living in their home. Only primary residences would be eligible.

But there is a second approach, based on the general theory of self selection. After the write down, the lender would retain a share (perhaps all) of the capital gain, to be paid when the property is sold. Speculators would have little (or no) interest in participating, since the debt restructuring would take away most or all of his speculative gains. (This makes this financial restructuring fully analogous to corporate restructuring.)

\section{Financial sector reorganization}

Financial markets are supposed to allocate capital and manage risk. America's financial markets did neither well. Products were created which were so complicated that not even those that created them fully understood their risk implications; risk has been amplified, not managed. But meanwhile, products that should have been 
created — to help ordinary citizens manage the important risks that they confront were not.

No one can claim that financial markets did a stellar job in allocating resources in the late 1990s, with 97 percent of the investments in fiber optics taking years to see any light. However, at least that mistake had an unintended benefit: as the costs of interconnections were driven down, India and China became more integrated into the global economy. This time, there were some short-term benefits from the excess investments in real estate, as some Americans enjoyed the pleasures of home ownership and living in a bigger home than they otherwise would have - for a few months. But at what a cost to themselves and the world economy!

We forgot that a financial system is a means to an end, not an end in itself. Indeed, the output of the financial sector in good accounting systems is treated as an intermediate good. Whatever benefits there are should be reflected in the higher output that its risk management and capital allocation services facilitate. A good financial system should be one that provides these services at low cost — using little of society's resources. Our financial system used up huge resources (or at least transferred large amounts of resources from other parts of the economy to itself), but didn't do what it should have done in return.

American banks mismanaged risk on a colossal scale, with global consequences. Meanwhile, those running these institutions have walked away with billions of dollars in compensation. By some estimates, close to 40 percent of corporate profits in recent years have accrued to the financial sector. To be sure, financial markets played an important role in providing finance to the truly innovative parts of the American economy, through venture capital firms, and these have been well rewarded for their services. But this is only a small part of America's financial system. From a systemic perspective, there appears to be a mismatch between social and private returns - and unless social and private returns are closely aligned, the market system cannot work well.

As we approach the problem of bailing out the banks, we should have begun by asking, what kind of financial system do we want in the future? Do we want to replicate the flawed model that got us into this mess? Should we return to a more bank-based lending system, or continue the securities based system? Almost 20 years ago, at the beginning of the era of securitization, I predicted that there was a good chance that it would end in disaster, as investors underestimated the problems posed by information asymmetries, the risks of price declines, and the extent to which risks are correlated. I was, regrettably, right.

Today, the issue on the table is what to do with our failing banks. At last, people are beginning to talk about the possibility of nationalization. Yet the Administration seems reluctant. I believe that the result is that we will fail in the twin objectives set out by President Obama: restart lending and preserve our nation's financial well-being. Under current proposals, there will not be a robust recovery of lending, and yet our national debt will soar, compromising our ability to achieve the many other lofty goals that the President set out so clearly and forcefully.

The banks have succeeded in instilling fear of bankruptcy and nationalization. I want to explain why both fears are unfounded and why temporary nationalization may be the only rational course of action. I want to present what I call Plan B - an alternative to the series of ad hoc measures that have characterized the bank bailouts since they began. But first, I want to spend a few minutes setting the scene and laying out a few principles and criteria for what defines a good plan. 
The unwarranted fear of financial reorganization. Financial reorganization is a standard part of modern capitalism that is necessary and inevitable when a firm's liabilities are in excess of its assets. In the case of banks, financial reorganization occurs prior to the certainty that the bank's assets are short of the liabilities, because of the risk of malfeasance and excessive risk taking ("gambling on resurrection") for undercapitalized institutions.

A second difference with standard financial reorganization arises from the fact that the government insures deposits, which are the most important class of liabilities of a bank. The government, however, does not insure other claimants, including equity holders.

Long experience has shown that financial reorganization can be done in ways with minimal trauma to the economy; even when there is extensive trauma (as in Argentina), the economy can recover relatively quickly. Experience too shows that delay can be extremely costly, both to the bank, in terms of the fiscal burdens when the financial reorganization eventually occurs, and to the economy, because during the interim there may be insufficient lending and because, as I noted, undercapitalized banks (zombie banks) have an incentive to engage in excessive risk taking and fraudulent behavior.

The unwarranted fear of temporary nationalization. Temporary government management can and has been done both abroad and in America in ways that avoid politically connected lending, by the Federal Deposit Insurance Corporation (FDIC) and Federal Savings and Loan Insurance Corporation (FSLIC). Indeed, in the experience of many countries, replacing old management and providing better incentive structures can lead to improvement in performance. Of course, the performance of America's financial institutions over the past 5 years sets, indeed, a very low bar. Moreover, the idea that reorganization means long-term government ownership is just wrong.

The government is, in fact, already actively involved in lending (through the Fed) and has totally distorted risk markets. How the government resolves the current crisis may impair the ability of risk markets to perform their essential credit and risk allocation functions for years to come. Markets are now pricing not the intrinsic risk of the asset or activity but the risk of a government bailout. More extensive bailouts will heighten this political and non-economic aspect of risk assessment.

Much of what we have done in the last few months has been motivated by irrational fear - fear that if we do not bail out the banks, there will be economic collapse, and fear that if we nationalize the banks, it will be the end of capitalism as we know it. To be sure, what we have done in the last few months has changed the nature of capitalism as we have known it. We have socialized losses, while leaving profits in the private sector. This form of ersatz capitalism, or corporate welfarism, call it what you will, is doomed to failure. It will result in resources being misallocated and wealth being redistributed in adverse ways.

Most importantly, we have failed even to distinguish between saving the banks and saving the bankers and particular categories of claimants (such as equity holders).

\section{Criteria}

The purpose of a bailout - from the national perspective - is not enhancing the well-being of our bankers who have served our country so poorly. Nor is the purpose the enrichment of the shareholders, who made ample gains in the heady 
days prior to the crisis. This means, of course, that what happens to their stock price is not a good barometer of a good plan. Indeed, we should be worried by any plan that sees bank shares rise, as the plan announced by Treasury does.

There are four key criteria:

1. Is there a rekindling of good lending? (It is not hard to restart lending - if the government bears all or most of the risk. This means that there have to be appropriate incentives in place.)

2. Is the cost to the government the smallest possible?

The cost to the government is especially important, given the legacy of debt from the Bush Administration which I noted earlier. The $\$ 350$ billion that has already gone out the door under the Troubled Asset Relief Program (TARP) is a reminder how quickly the government can go through money with little to show for it.

President Obama has laid out these principles, but, as I shall shortly explain, the bailouts do not measure up to the mark. But there are two other criteria that are also important.

3. The solution to the current problem should make it less likely, not more likely, that we have problems in the future. The agglomeration of banks - making them even more too big to fail - is a concern. The way we have been bailing out the bankers and their shareholders is giving rise to unnecessarily large problems of moral hazard going forward.

4. The bailout should conform to high standards of transparency and good governance. What we have done has provided a model to other countries - of what should not be done, except in one respect: the Congressional Oversight Panel, which is finally beginning to shed some light on the extent to which the American people have been cheated and continue to be cheated.

\section{Principles to guide restructuring}

There are eight equally simple principles.

1. Conservation of matter. Moving assets and liabilities around, to a first order, does not create value. When the government insures the losses of, say, Citibank, the losses don't disappear. They simply move from Citibank's balance sheet to the government's balance sheet - but because of government accounting, we may not be fully aware of this. Similarly, if we remove toxic assets from the banks' balance sheets, the toxic assets haven't disappeared. They are as much a part of the economy as they were before. If we move them to a Bad Bank, they appear on the balance sheet of the "Bad Bank" - under most proposals, again, with losses to be borne by taxpayers.

2. This means the real battle is thus about redistribution: who bears the losses? Will it be shifted away from the financial sector onto the public? In a zero sum world, a better deal for the banks means a worse deal for the taxpayers.

That is why what has been happening is so troubling. The Congressional Oversight Panel reported that in the major transactions under TARP, the US got about 67 cents on the dollar in preferred shares - but what we got has since sunk in value, as many of us expected would happen. We got a raw deal.

But what happened under the Bush Administration may look good in comparison to what was announced in the third Citibank bailout, which allows Citibank to convert preferred shares to common shares. While the full calculation of the value of the deal will take a while, preliminary calculations suggest we are 
getting something like 25 cents on the dollar. If those representing us in the government had been working for Wall Street, and this is the best their bargaining could have done, they would have long ago been fired.

3. Trickle down economics is in general inefficient. If one is worried about the consequences of a decrease in the value of, for example, a bond held by an insurance company, it is not a good use of taxpayers' money to preserve all bondholders. It is better to focus attention on those who are specifically in need. There is worry, for instance, that if we do not bail out all creditors, some insurance and pension funds may experience significant losses. They are being put forward as "socially worthy" claimants. But already, there is discussion of cut backs in social security. The funds that might trickle down to these private claimants are funds that might go to strengthen the social security system, avoiding deeper cutbacks. To which should we give greater weight, those to whom we have made a social contract, or those who have made bad investment decisions? In the end, there will have to be shared sacrifice. Plan B is an attempt at a fair and equitable solution, and one that is consistent (so far as possible) with principles of market economics. If we need to rescue pension funds and or insurance companies, then we should do so directly, where every dollar of government money goes directly to the group that needs it. Spending \$20 to bail out investors so that $\$ 1$ can go to a pension fund is foolish.

4. Incentives matter - and if we don't get incentives right, we won't have good outcomes. Bailouts represent nearly a zero sum game. However, if they are not structured correctly, there can be a negative sum game. For instance, some of the proposals being bandied around entail the federal government providing insurance against losses. This, of course, increases a virulent version of the moral hazard problem - when market participants don't bear the full consequences of their actions, they are likely to take actions that are not in the overall interests of society. Insurance gives rise to moral hazard problems. More generally, systems in which ownership and control are disparate give rise to perverse outcomes.

5. Lending is a matter not just of the ability of the banks to lend, but also of their willingness to do so. Other factors besides the ability to lend affect lending: specifically, the riskiness of the banks' balance sheets and the riskiness of new lending. The promised positive sum benefits from an improvement in banks' balance sheets will not arise if new lending is viewed to be excessively risky.

It is apparent that those structuring these programs have not thought deeply about the determinants of credit flows. In fact, these concerns should be at the center of any monetary theory. Bruce Greenwald and I, in our book Towards a New Paradigm of Monetary Economics [2003], explain the other factors that affect lending - among which is the risk, which has only grown worse as the economy's woes have deepened.

6. Look to the future, not the past. We need to be looking forward, not looking back - there is a basic principle in economics that bygone are bygones. Yet most of our attention is focused on the past and is not forward looking. Instead of trying to save all existing banks, consider what we might have done with $\$ 700$ billion had we established a set of new banks, or given it to the few healthy and well-managed banks. At a modest 12 to 1 leverage, that would have generated \$8.4 trillion of new credit - more than enough for our economy's needs. Even if we had not done anything so dramatic, using more of the money to absorb some of the uncertainty of new loans - as some governments are 
doing - would have yielded far higher social returns than America's failed strategy while forcing appropriate discipline on the banks, rewarding those that had been prudent and letting fail those that had taken extraordinary risk.

7. Financial reorganizations - giving a fresh start - are not the end of the world. Indeed, it can represent the beginning of a new world, one in which incentives are better aligned and in which lending will be rekindled. Financial reorganization has become a fact of life in many industries, such as the airline industry; many banks have been smoothly reorganized - a period during which the government runs them is followed by privatization. With failed management bearing the consequences of the mistakes and with past obligations reduced, the banks are able to "move on." Customers can be served better, and investors will be more willing to put money into such a restructured organization.

8. The Polluter Pays Principle. In environmental economics, there is a basic principle, called the Polluter Pays: it is not just a matter of equity but also a matter of efficiency. American banks have polluted the global economy with toxic waste, and it is a matter of equity and efficiency - and of playing by the rules - that they must be forced, now or later, to pay the price. This is not the first time that American banks have been bailed out. It has happened repeatedly. The implication is that, in effect, this sector is being heavily subsidized by the rest of the economy. Only by making sure that the sector pays the full costs of its actions will efficiency be restored.

\section{An outline of a plan}

1. Assessment of viability of banks; those banks that are not viable should be given short notice to find sufficient funds to recapitalize to an adequate level or be taken over. This assessment should be based both on stress tests and on a valuation of assets on a mark to market basis. Both of these methodologies have flaws and limits; the combination, especially if the stress test is done against a "tough" scenario of a prolonged downturn with marked declines in real estate prices and marked increases in unemployment and default rates, should give us more confidence in the results. The problem is that the models used in the past for stress testing were badly flawed - what confidence do we have that they will do better going forward than they have in the past?

2. Deposits and other liabilities for which the government has already issued guarantees would be fully honored. Other liabilities would be divided into three categories: $A, B$, and $C$. Category $A$, the most senior or whose failure would pose the most systemic risk, would be fully insured, upon payment of a 10 percent insurance premium. Categories $B$ and $C$ would similarly be insured for $2 / 3$ and $1 / 3$ of their face value, upon payment of a 10 percent insurance premium. This would provide surety and liquidity to the market, without imposing undue and unwarranted costs on the government for picking up liabilities for which it has no responsibility.

3. Deposits in foreign branches and subsidiaries would be fully guaranteed upon the payment of the 10 percent insurance premium (Anti-contagion provision). The US Government, perhaps through the Fed, would make available financing for countries to pay the premium, with the repayment subtracted from the actual payments made under this provision. This facility might be extended to other foreign creditors, particularly from developing countries. 
4. The fully insured liabilities and the "good assets" - those that can be valued with some degree of certainty - would be stripped out of the failed institution, forming a Good Bank. The remaining assets and liabilities would remain with the Bad Bank. The Bad Bank would provide an insurance policy to the Good Bank on the value of the assets stripped out, analogous to that provided by the government to Citibank (the Good Bank would bear the first 10 percent of losses, the Bad Bank all losses in excess of that). If the value of the assets exceeds the value of the liabilities, the Good Bank would pay the Bad Bank the difference; in the reverse case, the difference would be a senior liability of the Bad Bank. Shareholders in the Bad Bank would be given a rights issue to recapitalize the Good Bank to a high level, well in excess of that required to weather a strenuous stress test. The Government would provide any deficiency in capitalization and receive proportionate voting shares. The Bank would be run on Commercial Principles.

5. The Bad Bank, undercapitalized, would not be able to accept deposits. It would be responsible for unwinding the assets, charged with maximizing the value to the claimants, with claimants satisfied in the order stipulated by the Bankruptcy proceedings.

6. Derivative and other positions would be netted and closed out, with any shortfalls owed to others being treated as claimants according to standard Bankruptcy proceedings.

7. Any State Insurance Fund bearing losses that are beyond its ability to pay as a result of the default on senior debt might apply for funds from a Compensation Fund, to be established out of a 10 percent levy on the net profits of any Good Banks established during these Proceedings. The Compensation Fund could pay up to one-third of the short fall, with one-third being borne by the State and one-third by the Policy Holder, for policies up to a limit to be determined. Similar provisions might be adopted for insured pension funds or other entities.

Plan B would provide security to the market, without rewarding those that have been speculating on a government bailout of bonds. It is not only sensitive to the global ramifications of the failure of a major international bank and to our responsibility to try to maintain stability of global financial markets, but it is also sensitive to the limited responsibility of American taxpayers to compensate for bad investment decisions made either in America or abroad. Finally, it is sensitive to the social consequences of a default, reflecting the principle of shared sacrifice but targeting the sacrifice of American taxpayers towards those who are more deserving or in need.

There are many variants of restructuring. Plan B is presented to show that there are concrete alternatives to the current strategy. Each of us may have our own preferred variation, but the point is that this approach, whatever the variation, is more likely to be better in achieving our national objectives than Plan A - the constantly evolving sets of plans that have only one thing in common: the avoidance of temporary nationalization. As President Obama has often said, we need bold action; inaction is not an option. But it matters which action. There are risks in any course of action, but Plan A, while it risks failing to restart lending, also risks a vastly larger national debt at the end of the day. The chorus calling for some version of Plan B is growing daily. 


\section{LESSONS FOR ECONOMICS}

I want to turn now to my second topic - lessons of this economic crisis for economics. The Great Depression transformed economics. Even as the economy sunk into depression, the mainstream of the economics profession argued that nothing should be done, as government intervention would only make things worse. As the depression faded into distant memory, the economics profession lost sight of these lessons. Dogmas and doctrines holding that markets worked well and that they were self-correcting once again came to predominate. This time, the theories were more sophisticated, but the underlying assumptions were equally irrelevant. These ideas helped shaped the intellectual milieu which gave rise to the flawed policies that, in turn, gave rise to the crisis, and to some extent, they are shaping policies today as we attempt to respond to the crisis.

The advocates of perfect markets in all their versions say that crises are rare events - though they have been happening with increasing frequency, as we change rules to reflect beliefs in perfect markets. I would argue that economists, like doctors, have much to learn from pathology: we see more clearly in these unusual events how the economy really functions.

In the aftermath of the Great Depression, a peculiar doctrine came to be accepted, called the neo-classical synthesis. It argued that once markets were restored to full employment, neo-classical principles would apply — the economy would be efficient. We should be clear: it was not a theorem but a belief. The idea was always suspect - why should market failures only occur in big doses? Rather, recessions can be seen as the tip of the iceberg; underneath are many "smaller" market failures, giving rise in the aggregate to huge inefficiencies - illustrated by a myriad of tax paradoxes.

We should remember too that while mega-failures have been rare in the US, on a global scale failures have in fact been frequent. This is just the largest and most recent of financial crises - and bailouts. Beyond America's S \& L debacle are bailouts with country names (Mexico, Brazil, Korea, Indonesia, Argentina, Thailand, Russia, etc.), which were really bailouts of western lenders, a result of inadequate assessment of credit worthiness. The main difference between these crises and the current one is that consequences were felt in "periphery" — and the costs of bailouts were largely borne in the periphery.

The irony, of course, was that other strands of modern economic theory, including the theory of imperfect information to which I have contributed, were simultaneously explaining why markets often do not work so well. Bruce Greenwald and I, for instance, showed that the reason that Adam Smith's invisible hand often appeared invisible was that it was not actually there: market equilibria were not constrained Pareto efficient whenever there were information imperfections and asymmetries and imperfect risk markets - that is always. At the same time, the most successful countries - ever - in growth and poverty reduction, the countries of East Asia, followed policies with active government involvement. One would have thought that this powerful combination of theory and evidence might have dampened the enthusiasm for unfettered and under-regulated markets. But evidently it did not. I understand the unbridled enthusiasm of special interests, which found the arguments for deregulation profit enhancing; I am not so clear what motivated so many economists.

Some have argued that risk is the price we have to pay for innovation, and America's financial markets have been extraordinarily innovative. However, 
financial markets did not create risk products that would have enabled individuals to manage the risks that they faced - the simple risk of home ownership. Rather, the innovations consisted mostly of tax, regulatory, and accounting arbitrage. Their financial alchemy - converting F-rated toxic mortgages into financial products that could be held by fiduciaries - had a private (but not necessarily social) pay-off. Such repackaging, we know from the Modigliani Miller theorem, should have at most limited value. Meanwhile, many in the financial sector actually resisted innovations that would have made markets work better innovations like GDP and inflation indexed bonds, Danish mortgage bonds, and better auctions of Treasury Bills.

The models that have predominated within macro-economics, which assume representative agents with rational expectations, are particularly disturbing. What I find even more striking is that some economists still argue that this crisis has not shaken their belief in rational expectations.

To me, the evidence of irrationality, and intellectual inconsistency, abounds. To give a few examples:

Markets believed that real estate prices could continue to go up - a necessary belief for the toxic mortgages not to blow up - and yet the real incomes of most Americans were decreasing.

Markets seemed to systematically ignore the possibility of highly correlated movements in housing prices, even though these prices are affected by interest rates that are determined nationally and by the overall business cycle, and markets seemed to ignore even the possibility of "contagion" from the interconnectivity of economic activity and expectations.

"Once in a lifetime" events happened every 10 years. They should have used fattailed distributions rather than lognormal distributions. There already were several instances of failures from using these models - evidently, financial markets did not learn.

Markets offered 100 percent or more non-recourse mortgages. They should have recognized that (at least with rational buyers) these were an option, with positive value: they were giving away money. It is not the standard model of banks to give away money - at least to poor people who they do not know. Both investors and regulators should have smelled that something was wrong.

Advocates of the new products argued that they were transforming the economy - it was only by such fundamental transformation could one justify the high salaries they were receiving. Yet in modeling, they used past data that, implicitly, assumed nothing had changed.

However, something had changed - new asymmetries of information had been created, which investors did not fully appreciate and did not take into account in their modeling. Mortgages were given with much higher default rates.

The system was rife with perverse incentives - on the part of rating agencies, on the part of mortgage originators, on the part of those participating in securitization, and on the part of banks. There were conflicts of interest, incentives to provide distorted information, and incentives to engage in short sighted and excessively risky behavior. But somehow, investors - the other side of each of these transactions - irrationally assumed that these perverse incentives had no adverse effects.

We allowed banks to get too big to fail but failed to take into account the effects that that would have on their behavior. 
Derivatives have played an important role in amplifying the crisis. The big banks failed to net out derivative positions. Evidently, they failed to recognize the importance of counterparty risk, even as they were betting on the failures of counterparties - another example of intellectual incoherence.

I could go on, but the point should be clear: even if individuals were acting in ways that were individually rational, the outcomes were not systemically rational.

Even today, flawed thinking continues. We are encouraging mergers among the big banks that cause them to be even bigger. We talk about tight regulation of systemically significant institutions, failing to note that there can be systemic effects of correlated behavior on the part of individual institutions, even if each is not systemically significant.

Representative agent models ignore the rich diversity of our economy - a diversity that is at the heart of some of the problems it faces. An economy with a single individual has no lenders and no borrowers, no problems of asymmetric information (unless individuals are subject to schizophrenia), no need for banks, no need to ascertain creditworthiness - in short, it is missing everything that is important. Remarkably, much of the economics profession focused on models that have almost nothing to say about the crisis we are facing.

There were alternative strands of thought. Minsky has come back into fashion. Greenwald and Stiglitz developed formal models of debt deflation and a theory of monetary policy focusing on the role of credit. With Gallegati and other co-authors, we have explored the credit interlinkages that have played such an important role in this crisis. These models explore the possibility of bankruptcy cascades. They explain how global financial integration may serve not only to share risk but also to facilitate contagion, as a failure in one part of the economic system - in this case, the US — spreads around the world. ${ }^{1}$ Neo-classical models argued that globalization inevitably led to more stability. Even before this crisis, there was mounting evidence to the contrary.

Let me turn now to monetary policy. Much of the profession focused again on simplistic models worried about the fourth order distortionary effects of low inflation, while ignoring the first order systemic effects of market fragility. They seemed to believe that low inflation was necessary and almost sufficient to ensure high growth and economic stability. They were clearly wrong. Worse, excessive focus on inflation may have distracted attention from what was going on - because inflation was low, they felt content even as leverage and risk was exceeding all reasonable bounds.

There are other arguments against inflation targeting - especially in open, developing countries. Those countries that tried to dampen this imported inflation were distorting their economy; nothing they could do would affect the prices of oil or food. In some cases, only 25 percent of the prices were directly affected by the high interest rates - to bring down average inflation imposed an enormous price on those sectors at the time. But the high interest rates led to high exchange rates, which have now fallen, subjecting the real sector to huge volatility. The attempt to stabilize inflation has served to destabilize the overall economy.

Let me conclude. Hopefully, we will learn, at least for a while, some important lessons from this crisis. Unfettered financial markets do not work, and the current regulation and regulatory institutions failed - partly because one is not likely to get effective regulation when there are regulators who do not believe in regulation. Markets are not self-adjusting, at least in the relevant time frame. 
More broadly, Darwinian natural selection may not work. Rather, like Gresham's law - which holds that bad money drives out good - reckless firms forced more conservative firms to follow similarly reckless investment strategies. More prudent firms might have done better in the long run but could not survive to take advantage of that long run.

Our financial system failed in its core missions - allocating capital and managing risk - with disastrous economic and social consequences, not just the misallocated capital of the past but the huge disparity between potential and actual GDP in the coming years, sums in the trillions of dollars. Regrettably, flawed economic theories aided and abetted both those in the public and in the private sector in pursuing policies that, almost inevitably, led to the current calamity.

We need to do a better job of managing our economy, but this will require better research that is less framed by the flawed models of the past, less driven by simplistic ideas, and more attuned to the realities of today. There is a rich research agenda ahead.

\section{Acknowledgement}

Financial support from Ford, Macarthur, Hewlett, and Rockefeller Brothers Foundations is gratefully acknowledged.

Note

1. See Battiston, 2007; Gallegati et al., 2008 and Delli Gatti et al., 2008.

\section{References}

Battiston, S. 2007. Credit Chains and Bankruptcy Propagation in Production Networks. Journal of Economic Dynamics \& Control, 31(6): 2061-2084.

Delli Gatti, D., M. Gallegati, B. Greenwald, A. Russo, and J.E. Stiglitz. 2008. Business fluctuations and bankruptcy avalanches in an evolving network economy, mimeo.

Gallegati, M., B. Greenwald, M. Richiardi, and J.E. Stiglitz. 2008. The Asymmetric Effect of Diffusion Processes: Risk Sharing and Contagion. Global Economy Journal, 8(3). Article 2.

Greenwald, B., and J.E. Stiglitz. 2003. Towards a New Paradigm in Monetary Economics. Cambridge: Cambridge University Press. 
Copyright of Eastern Economic Journal is the property of Palgrave Macmillan Ltd. and its content may not be copied or emailed to multiple sites or posted to a listserv without the copyright holder's express written permission. However, users may print, download, or email articles for individual use. 